\title{
Can fiscal decentralization alleviate government consumption volatility?
}

\author{
Davide Furceri \\ IMF and University of Palermo (Italy) \\ E-mail: dfurceri@imf.org \\ Agnese Sacchi \\ 'Universitas Mercatorum' University (Italy) \\ E-mail: a.sacchi@unimercatorum.it \\ Simone Salotti \\ Oxford Brookes University (UK) \\ E-mail: ssalotti@brookes.ac.uk
}

\begin{abstract}
We analyse how fiscal decentralization affects the volatility of government consumption extending the existing literature that mainly deals with the effects of the former on government size. Using data for 97 developed and developing countries from 1971 to 2010, we find that a higher degree of fiscal decentralization leads to lower government consumption volatility. This result holds for the subsample of advanced economies, while it is not confirmed for those less-developed. This mechanism seems to work mainly through a lower volatility of the non-discretionary spending, which typically belongs to the central government's policy. We also confirm existing findings according to which country size lowers government spending volatility. Thus, given a minimum level of development, fiscal decentralization reforms can offset volatility by distributing power to sub-central governments, with particular benefits for smaller countries usually more prone to volatility.
\end{abstract}

Keywords: fiscal policy, fiscal decentralization, spending volatility, automatic stabilisers, country size

JEL classification: $\mathrm{H} 60, \mathrm{H} 71, \mathrm{H} 72$, E62 


\section{Introduction}

There has been a surge of interest in fiscal decentralization due to recent widespread reforms aimed at increasing it in both developed and developing countries (see, among others, Arzaghi and Henderson 2005, Bodman and Hodge 2010). On the one hand, many traditionally "unitary" European countries (such as France, Italy, and the United Kingdom) substantially revised their fiscal apparatus, and some of them are now virtually indistinguishable from federalist countries (Ter-Minassian 1997; Stegarescu 2005). On the other hand, some federal countries increased the already significant levels of autonomy granted to sub-central government tiers (e.g., Australia - Blöchliger and Vammalle 2012). Decentralization has also increased in a number of transition countries in Eastern Europe and central Asia such as Nepal, the republics of the former Soviet Union and Yugoslavia (Dabla-Norris 2006). Overall, in most countries the fiscal responsibilities assigned to lower government levels have increased (OECD 2012).

The existing literature offers a number of studies on the effects of fiscal decentralization on many economic variables, such as regional and national economic growth (Martinez-Vazquez and McNab 2003; Thornton 2007; Rodriguez-Pose and Ezcurra 2011), output volatility (Nishimura 2006), economic integration and openness (Garrett and Rodden 2003; Stegarescu 2009), inflation (King and Ma 2001), institutional quality and corruption (Fisman and Gatti 2002; Kyriacou and Roca-Sagalés 2011), poverty and income distribution (Sepulveda and Martinez-Vazquez 2011; Sacchi and Salotti 2013), and government size at both aggregate and local levels (Jin and Zou 2002; Fiva 2006; Prohl and Schneider 2009; Cassette and Paty 2010; Liberati and Sacchi 2012).

The latter strand of literature is particularly related to the present paper, given the potentially close link between government size and its volatility: the larger the former, the higher is likely to be the latter. Beyond this, there is a widespread agreement in previous studies on the fact that the size of the public sector can be smaller when decentralization is funded by own taxes, and comparatively larger when funding comes from central government grants according to the common pool hypothesis (Rodden 2003). In this respect, while the impact of fiscal decentralization on the size of the public sector has been widely studied, the influence of the former on the volatility of government spending has been overlooked by the literature.

The importance of government consumption volatility lies in its effects on the economic performance. While in principle a certain degree of volatility may be beneficial to smooth out the effects of economic shocks on the business cycle, most studies find that higher volatility of government spending is detrimental to economic growth and welfare (Fatas and Mihov 2003 and 2005, Furceri 2007, Afonso and Furceri 2008, Loayza et al. 2007). In a recent study, Furceri and Ribeiro (2009) suggest that government spending volatility is related to the size of a country, where smaller countries are characterized by higher volatility.

The aim of this paper is to study the influence of fiscal decentralization on government consumption volatility, something that has never been studied before (to the best of our knowledge). 
There are many ways in which decentralization may affect the volatility of government consumption, involving both direct and indirect channels. We devote the next section of the paper to their illustration, and we rely on our empirical analysis for their investigation.

We contribute to the existing literature along the following lines. We look at how fiscal decentralization affected government consumption volatility in a large sample of 97 developed and developing countries in the last 40 years. Second, we utilize different series and sources to measure fiscal decentralization to ensure the robustness of our empirical analysis. In particular, we use both the IMF's Government Finance Statistics (GFS) data (retrieved from the World Bank - WB from now on) and more updated OECD data available for a subsample of developed countries. Finally, we investigate the various channels that may be at work in the decentralization-volatility relationship by estimating several specifications of a comprehensive and rich empirical model.

The main results of our empirical analysis can be summarized as follows. i) According to simple bivariate models, more fiscally decentralized countries have less volatile government consumption.

ii) When controlling for regional, institutional, demographic, and macroeconomic variables, it emerges that the negative relationship holds for advanced economies only. iii) This result seems to be due to lower volatility of the non-discretionary government spending (i.e. the automatic stabilisers, which typically pertain to the central government's budget). iv) We confirm that country size is negatively associated with government volatility, as suggested by previous studies. v) Larger government size (measured by the government consumption share of real GDP per capita) increases government consumption volatility; this is independent from the degree of decentralization, but it only holds in developed countries. Overall, we conclude that fiscal decentralization reforms can offset volatility by distributing power to sub-central governments. This may advantage smaller countries that are usually characterized by higher government consumption volatility.

The remainder of the paper is organized as follows. Section 2 describes the potential channels through which the relationship between fiscal decentralization and spending volatility may take place. Section 3 illustrates the empirical strategy and the variables used in our analysis. Section 4 presents and discusses the estimation results. Finally, section 5 concludes and provides some policy implications.

\section{Theoretical channels between decentralization and consumption volatility}

Having expenditure and taxing powers distributed across many tiers of government may affect the volatility of government consumption both directly and indirectly. As for the former, many subjects with small individual budgets (i.e., a highly decentralized country) should produce a different total expenditure in terms of volatility with respect to a single subject with a bigger allocation of resources (i.e., a centralized country). An intuition for this is provided by what happens in power markets, where distributed generation lowers price volatility (Coles and Beck 2001). The finance literature offers another parallel, since markets with more participants tend to exhibit lower volatility 
(Demirgüç-Kunt and Levine 1996). Therefore, having spending and revenue decision powers spread across more tiers of government may directly lower consumption volatility.

There are also a number of potential indirect channels through which various degrees of fiscal decentralization may yield different consequences on the volatility of government consumption. First, high degrees of fiscal decentralization may imply a lower importance of automatic stabilisers, instruments that are typically in the hands of central governments. ${ }^{1}$ In fact, according to the traditional theory on fiscal federalism (e.g., Musgrave 1959), the macroeconomic stabilization function should be given to the central government and not be subject to the decentralization process. Existing studies find that in countries where revenues and expenditure responsibilities are largely decentralized it emerges a lower growth of central government size (e.g., Prohl and Schneider 2009), which in turn may result in a reduced role for automatic stabilisers. This would also imply less volatility arising from this important part of government consumption, representing the non-discretionary component of government spending. ${ }^{2}$

Second, decentralization reforms may increase fiscal discipline, therefore resulting in lower spending volatility of its discretionary component, this time. There is empirical evidence supporting the beneficial effect of fiscal decentralization in improving public finances by reducing the budget deficit (e.g., Neyapti 2010; Escolano et al. 2012) and promoting the country's fiscal discipline. ${ }^{3}$ In this context, we may expect governments to rely less on discretionary fiscal measures, i.e. the spending component linked to exogenous political processes and/or extraordinary non-economic circumstance (Fatas and Mihov 2003; Afonso et al. 2010).

Third, but related to the previous points, fiscal decentralization may affect government spending volatility by influencing aggregate government size. In the literature there is a wide consensus on the fact that fiscal decentralization usually leads to a reduction of the overall size of the public sector. The theoretical argument supporting this negative relationship is mainly ascribable to the competitive federalism theories (Brennan and Buchanan 1980; Salmon 1987; Breton 1987; Qian and Weingast 1997). ${ }^{4}$ Accordingly, fiscal and electoral competition among local governments makes them more accountable to local voters and serves to discipline potentially 'bad' politicians (reducing rent-seeking

\footnotetext{
${ }^{1}$ Automatic stabilisers have long been regarded as playing a key role in macroeconomic stabilization, mainly because they are not subject to the typical lags (information, decision and implementation) undermining the effectiveness of discretionary stabilization measures (see Debrun et al. 2008).

${ }^{2}$ Economists have long argued that the growing size of governments after World War II contributed to greater macroeconomic stability because of the near proportionality between the magnitude of automatic fiscal stabilisers and the size of government expenditure (Blinder and Solow 1974).

${ }^{3}$ Another finding in Neyapti (2010) is that the fiscal disciplining effect of fiscal decentralization increases with population size. In turn, in Escolano et al. (2012) spending decentralization is associated with stronger fiscal performance than revenue decentralization, especially when transfer dependency of sub-national governments is low.

${ }^{4}$ Actually, a negative relationship between fiscal decentralization and government size also arises from the traditional theory of fiscal federalism (e.g., Oates 1972), assuming a benevolent central policy-maker that can better take into account heterogeneous individuals' preferences by decentralizing the supply of local public goods. The main implication of this so-called 'Decentralization hypothesis' is that fiscal decentralization will again lead to greater efficiency overall and then to a leaner public sector.
} 
behaviour and the monopoly power of central and local governments). As the central government is considered a revenue-maximizing Leviathan, fiscal competition among local jurisdictions limits the central government's excessive taxing power and reduces the citizens' tax burden. Following this reasoning, decentralization may be efficient and characterized by a lower tax burden resulting in a smaller aggregate public budget (Marlow 1988, Shadbegian 1999, Rodden 2003, Fiva 2006, Ashworth et al. 2012). All in all, our interest lies in a smaller government size in more decentralized country being likely to lead to lower consumption volatility. Other studies focusing on government size - but neglecting the role of fiscal decentralization - also find a negative correlation between the former and the volatility of consumption (Andres et al. 2008) as well as output volatility (see, among others, Fatas and Mihov 2001 for both the OECD countries and across the USA).

Fourth, there may be potential interactions between decentralization and government volatility through the link between the former and country size (i.e. population), given the importance of the latter in affecting government volatility (e.g., Furceri and Ribeiro 2009). The relationship is hardly unambiguous: a larger population may call for higher decentralization due to demand and supply considerations (Panizza 1999; Letelier 2005; Shelton 2007), but it can also potentially favour economies of scale in the provision of public goods and services at the central level, therefore lowering decentralization (Ashworth et al. 2012).

Finally, fiscal decentralization may affect institutional quality (in a positive way, according to Kyriacou and Roca-Sagalés 2011) and, in turn, the volatility of government consumption. Next section is the starting point of our empirical analysis trying to shed light on all of these themes.

\section{The empirical strategy: model and variables}

We use data for 97 countries (listed in the Appendix) over the period 1971-2010, although data coverage varies depending on the different sources used. For instance, OECD fiscal decentralization data cover the whole time period, but the WB decentralization indicators do not go beyond 2000.

Different model specifications are used in order to investigate the effects of fiscal decentralization on government consumption volatility. We start from a very parsimonious model (i.e. a bivariate) and then gradually enrich it with additional sets of control variables (for similar applications, see Rose 2006, Furceri and Karras 2008). The most comprehensive specification is therefore the following:

$$
G C_{-} \operatorname{vol}_{i,[t, t+4]}=\alpha_{i, 0}+\alpha_{i, 1} f d_{i, t}+\boldsymbol{\beta}_{i, j}^{\prime} \mathbf{r e g}_{-} \text {inst }_{i, t}+\boldsymbol{\beta}_{i, k}^{\prime} \text { demo }_{i, t}+\boldsymbol{\beta}_{i, l}^{\prime} \mathbf{m a c r o}_{i, t}+\tau_{t}+u_{i, t}
$$

where $G C_{-} v o l_{i,[t, t+4]}$ stands for government consumption volatility, which is defined as the standard deviation of annual growth of real government consumption spending over five-years. ${ }^{5}$ All the right-

\footnotetext{
5 We use two alternative measures for robustness purposes, finding that the choice of how to measure government consumption volatility does not alter the results. In particular, results hold when using the standard
} 
hand-side variables are instead taken at time $t$, the beginning of the five-year periods, in order to deal with potential reverse causality issues.

Our main variable of interest is fiscal decentralization, $f d_{i, t}$, for which we have two alternative measures from each of the two main data sources, WB and OECD: expenditure decentralization (namely $e d \_w b_{i, t}$ and $e d \_o e c d_{i, t}$ ), and revenue decentralization (namely $r d \_w b_{i, t}$ and $r d \_o e c d_{i, t}$ ). These are the most commonly used indices used to represent fiscal decentralization in a comparative perspective and they are calculated as the ratio between sub-central expenditures (revenues) divided by total general government expenditures (revenues). The higher the values of these indices, the more decentralized the countries. We construct a third measure of decentralization, which is the simple average of $r d_{-}$and $e d_{-}$belonging to the respective sources (namely $f d_{-} w b_{i, t}$ and $f d_{-} o e c d_{i, t}$ ). It parsimoniously summarises the informative content of the other two measures and provides a comprehensive picture of the fiscal decentralization phenomenon considering both sides of the budget (see Akai and Sakata 2002; Thieben 2003 for similar applications). For the sake of brevity, in the next section we will only present the results referred to $f d \_w b_{i, t}$ and $f d \_o e c d_{i, t}$, as they are consistent with those obtained with the other indices.

In detail, the OECD data on expenditures (revenues) of each level of government are defined as total spending (revenues) minus the inter-governmental transfer spending (revenues) of that government level. In turn, consolidated general government expenditures (revenues) have been calculated as global total expenditures (revenues) at the general government level plus the total intergovernmental property expenditures (incomes). This addition is made because the latter represents payments by one level of government for a service provided by another government level and it essentially avoids consolidation of property expenditure (income) at the general government level.

WB decentralization indices are derived from IMF-GFS where sub-national data are aggregated across all governments within the same tier. It is important to stress that these data do not perfectly represent expenditure and revenue autonomy. Expenditures that are mandated by the central government appear as sub-national expenditures, even though sub-national governments may have no autonomy in these spending decisions. Likewise, a typical question is how much tax autonomy is captured by these indicators as, for example, shared taxes appear as sub-national revenue, although the sub-national government has no autonomy in determining the revenue base or rate (revenues are reported based on which level of government ultimately receives the revenues). ${ }^{6}$

deviation of the cyclical component of real government consumption obtained by applying the Hodrick-Prescott filter to annual data with two alternative smoothness parameters, 100 and 6.25 (see Ravn and Uhlig 2002). We avoid checking the results using the coefficient of variation as a third alternative due to its well-known problems in terms of potentially misleading negative values for countries with highly volatile government spending.

${ }^{6}$ Some attempts to overcome this shortcoming are those of Stegarescu (2005) and Gemmell et al. (2013), who built tax decentralization indices able to capture the real autonomy of sub-central governments over their tax decisions, avoiding overestimation measurement problems. However, the data coverage is limited in terms of countries and years. 
The most important difference between the two sources lies in the different data coverage. OECD data start in 1971 and end in 2010 for 29 of the 34 OECD countries. WB data exist for more countries (sometimes even for OECD countries for which there are no OECD data, e.g. Australia) but end in 2000 (refer to the Appendix for the lists of countries). This may, and indeed will, give rise to different empirical findings which we will comment upon accordingly.

As explained in Dziobeck et al. (2011), among others, sub-central levels of government include local, regional, provincial, and state (when existing) governments, as opposed to the central government. Therefore, the indices from both sources do not distinguish between the various tiers of government and all sub-central units aggregated into a single group. ${ }^{7}$ However, to the scope of our paper a further horizontal disaggregation would pose cross-country comparability issues and would damage the actual (and rich) data coverage.

Figure 1 reports the evolution of average fiscal decentralization (WB data) in different groups of countries over time. The data clearly show increasing fiscal decentralization in the developing countries of the sample, both low- and middle-income. This is particularly true in the Nineties, with decentralization being more or less constant in the first two decades of the period. Average fiscal decentralization also remained more or less constant in the group of OECD countries, but this masks large within-group variability (and the WB data obviously do not take into account the reforms post1999).

\section{INSERT FIGURE 1 ABOUT HERE}

Back to the empirical model in equation (1), the control variables are divided into three main groups. Firstly, reg_inst is a set of time-invariant regional and institutional indicators: a) language dummies (English, French, German, Dutch, Portuguese, Spanish, Arabic, Chinese); b) latm $_{i, t}$ is the log of absolute latitude (kilometres from the equator); c) regional/income dummies (1: high income; 2 : upper middle income; 3 : lower middle income; 4 : low income); d) $l a n d l_{i, t}$ is a binary dummy variable for landlocked countries; e) island $_{i, t}$ is an island-nation dummy; f) $C O M E C O N_{i, t}$ and $O P E C_{i, t}$ are two economic organization dummies for, respectively, the former countries of the Comecon and those members of OPEC; $\mathrm{g}$ ) independence $e_{i, t}$ is the year of independence.

Secondly, the set labeled demo contains the following demographic variables: a) pop $_{i, t}$ stands for the logarithm of total population, commonly used as a measure of country size (e.g., Alesina and Wacziarg 1998); b) $u r b_{i, t}$ stands for urbanization measured by the percentage of urban population over the total population; c) pop_dens $s_{i, t}$ is population density.

\footnotetext{
${ }^{7}$ This horizontal aggregation also disregards the differences in competencies among them (as the revenue decentralization data do not distinguish between tax revenues that are legislated and collected locally and those that accrue to the sub-central governments through revenue sharing schemes). Moreover, any information about the spending composition and the policy mix is actually lacking, thus making us unable to distinguish between the potentially different effects of, e.g., decentralized education versus health expenditure.
} 
Finally, macro is a set of macroeconomics variables: a) $g d p_{i, t}$ is the logarithm of real GDP per capita; b) inflation $_{i, t}$ is inflation calculated from the GDP deflator; c) open $_{i, t}$ is trade openness measured by the sum of imports and exports divided by GDP; d) fin_open $n_{i, t}$ is financial openness measured as the net foreign asset position; e) fin_depth $h_{i, t}$ is financial depth approximated by the ratio between bank credits and bank deposits. All these covariates are included considering their potential effects on government consumption volatility and in accordance with previous empirical studies.

We start with the bivariate model (labeled as specification A) where fiscal decentralization is the only regressor; specification $\mathrm{B}$ adds the set of regional and institutional variables to it; specification $\mathrm{C}$ extends $\mathrm{B}$ as it also contains the set of demographic variables; finally, specification $\mathrm{D}$ adds to the previous one the set of macroeconomic variables. $u_{i, t}$ is the disturbance term. We always include period dummies $\left(\tau_{t}\right)$ in order to control for external shocks that may affect more than one country at the same time. We estimate equation (1) using OLS with clustered standard errors.

Consistently with the theoretical framework described in Section 2, we also try to identify the indirect channels through which fiscal decentralization may affect government consumption volatility. We explore which is the prevailing channel between less discretionary volatility - basically due to more fiscal discipline favoured by more fiscal decentralization - and less volatility of automatic stabilisers - mostly due to lower size of central governments resulting from fiscal decentralization. Empirically, we disentangle spending volatility in these two components, i.e. volatility due to automatic stabilisers and volatility due to discretionary policy, and use them as dependent variables (one at a time) of equation (1). ${ }^{8}$ Finally, we estimate three alternative specifications where we add the interaction between decentralization and country size, government size, and a variable measuring institutional quality to model (1) separately one at a time.

In all cases, equation (1) is estimated using five-year non-overlapping periods either from 1972 to 2000 on a sample of 97 countries (when using the WB decentralization data) or from 1971 to 2010 on a sample of 29 OECD countries (when using the OECD decentralization data). The panel is unbalanced mainly due to missing values of the decentralization series. The Appendix contains the data description and sources used in the analysis.

\section{INSERT TABLE 1 ABOUT HERE}

A first look at the data suggests that there may be a negative relationship between government consumption volatility and fiscal decentralization. Table 1 contains the correlations between the

\footnotetext{
${ }^{8}$ In order to generate these variables, we follow Fatas and Mihov (2003) and Badinger (2009), regressing annual growth of government consumption on its lagged value, growth of output on annual basis (on a country-bycountry basis), adding inflation, squared inflation and a time trend as controls. We instrument output growth using two of its lags and the logarithm of the oil price. Then, we computed the 5-years standard deviation of the fitted values (to be interpreted as volatility due to automatic stabilisers) and the 5-years standard deviation of the residuals (volatility due to discretionary policy). See the Appendix for more details.
} 
former and the six measures of the latter, showing that all are negative and statistically significant at standard levels. Simple scatter plots support this initial finding both in the large sample obtained with WB data (Figure 2) and in the smaller sample of developed countries obtained with OECD data (Figure 3). We turn to the econometric analysis to make more robust statements.

\section{INSERT FIGURES $2 \& 3$ ABOUT HERE}

\section{Estimation results}

\subsection{Baseline model}

Tables 2 and 3 report the estimated coefficients of model (1) using, respectively, the dataset with WB decentralization data and that with the OECD ones.

\section{INSERT TABLES $2 \& 3$ ABOUT HERE}

The bivariate specifications suggest that there is a negative and statistically significant relationship between fiscal decentralization and government consumption volatility. When using $f d \_w b$, this result holds both for the whole sample and for the sub-sample of OECD countries, but not for that of non-OECD countries (Table 2, A columns). This initial finding is confirmed by the estimates done with $f d \_o e c d$, with the fiscal decentralization coefficient (Table 3, A column) estimated to be negative (and even higher in magnitude than that in Table 2).

Results arising from the richer specifications (shown in columns B, C, and D of both Tables 2 and 3) yield additional evidence in favour of the negative relationship existing only in developed countries. Including data from the last decade proves to be crucial: even though both the $f d \_w b$ and the $f d \_$oecd coefficients are negative, only the latter are statistically significant at standard levels. ${ }^{9}$ This suggests that more fiscal responsibilities and competences assigned to sub-central governments yield more stable overall government consumption expenditure mainly in developed countries.

It is important to check whether the effect of decentralization on government consumption volatility is not only statistically significant, but also economically relevant. Focusing on the OECD indicators (Table 3), we note that 25 percentage points of fiscal decentralization can lower volatility up to $1 / 2$ standard deviation, ceteris paribus. For instance, Spain experiences less volatile government consumption with respect to France by $1 / 3$ standard deviation, due to the Spanish average fiscal decentralization level (for the whole period) being equal to $31 \%$, versus $16 \%$ of France. These values are certainly non-negligible, given the existing cross-country differences in the degree of fiscal decentralization.

\footnotetext{
${ }^{9}$ Indeed, the $f d \_$oecd coefficients become not significant when excluding post-2000 data (regressions not reported for the sake of brevity but available upon request).
} 
A possible explanation for this finding could lie in the fact that sub-central governments may find it hard to experience very large swings in spending/revenues year-by-year (given their necessarily smaller budgets with respect to the central government), resulting in a lower overall volatility of government consumption. Also, the increased number of institutional actors with more fiscal decision-power through decentralization may lead to lower volatility according to mechanisms similar to those occurring in financial markets where increased participation lowers price volatility (e.g., Pagano 1990; Allen and Gale 1994).

Interesting results arise from the inclusion of the various controls. For example, the level of development significantly affects the volatility of government consumption. The coefficients of the dummies identifying the various income groups demonstrate that lower income countries (income_3 and _4) and the former Comecon economies experience higher volatility than those with higher income (see Table 2). This is confirmed by the estimates with the OECD sample, where only uppermiddle-income countries (income_2) are included together with the high-income ones, and they result being characterized by more volatile government consumption with respect to the latter (i.e. the reference category).

Another remarkable result is the evidence of the negative effect of country size (роp) on government consumption volatility using both the WB and the OECD decentralization indicators, as already documented by Furceri and Ribeiro (2009). In fact, this variable may be positively related to fiscal decentralization considering the role of individuals' demand for specific local public goods and services (e.g., Panizza 1999; Letelier 2005; Shelton 2007). However, heterogeneity in population preferences may contrast with the exploitation of economies of scale in the provision of public goods and services when population size is large (e.g., Alesina and Spolaore 1997; Spolaore 2008; Ashworth et al. 2012).

Since larger countries are normally characterized by higher levels of fiscal decentralization (see Figure 4), the result could have been somewhat expected. However, the result of fiscal decentralization negatively affecting the volatility of government consumption remains even when controlling for country size, highlighting that the importance of the former may go beyond its correlation with country size.

\section{INSERT FIGURE 4 ABOUT HERE}

\subsection{The investigation of potential indirect channels}

We now turn to the investigation of the channels through which decentralization lowers the government consumption volatility as found above. The first step is to understand the component of government consumption which is most affected by fiscal decentralization. To this purpose, we substitute the dependent variable of equation (1) with, respectively, the volatility of discretionary consumption, and the volatility of the government automatic stabilisers. We obtain these series (as 
explained in Section 3 and in the Appendix) by following a well-established literature that started with Fatas and Mihov (2003).

Results are reported in Tables 4 and 5, following the same logic used in previous tables. We only report the results obtained with specification $\mathrm{D}$ as it is the richer and most comprehensive of all. Table 4 contains the estimates with $f d \_w b$ as the fiscal decentralization measure, while results obtained with the OECD data are reported in Table 5.

\section{INSERT TABLES 4 \& 5 ABOUT HERE}

Regardless of the sample and the decentralization indicators used, there is no discernible effect on the volatility of the discretionary component of government consumption. Therefore, we can rule out the idea of fiscal discipline acting as the channel between fiscal decentralization and lower consumption volatility. On the other hand, it seems that fiscal decentralization tends to lower volatility of the non-discretionary spending component, such as the automatic stabilisation measures typically linked to the central government's action, in OECD countries only. This result is statistically significant both with WB and OECD decentralization data, and the magnitude of the coefficients is similar (although higher when using $f d \_o e c d$ ). These findings suggest that fiscal decentralization, by shrinking the size of central governments, is successful in lowering the volatility of automatic stabilisers.

We now present other interesting extensions of our analysis by following the ideas put forward in Section 2. First of all, given the attention received in the literature by the role of country size on government consumption volatility, we study the potential interactions between fiscal decentralization and country size. To this purpose, we add to model (1) the interaction term obtained by multiplying the decentralization indicator by the logarithm of population. Then, we investigate two additional channels as follows: first, we include government size (measured by the government consumption share of real GDP per capita) in the set of right-hand-side variables. ${ }^{10}$ Second, we add a measure of institutional quality (assuming values between zero and one, with higher values indicating better quality) taken from the Quality Of Government dataset. It accounts for corruption, law and order, and bureaucracy quality. Results of these three enriched models are presented in Tables 6 (WB data) and 7 (OECD data). Once again, we only use specification D of the model.

\section{INSERT TABLES 6 \& 7 ABOUT HERE}

\footnotetext{
${ }^{10}$ There is a general agreement on using the ratio between public expenditures and GDP and this is mainly due to the fact that considering tax revenues only is likely to underestimate the actual government size since it would disregard all public spending and activities financed by debt and deficit.
} 
These new specifications yield no interesting results for the decentralization coefficients when using the WB data (Table 6), that is, when restricting the sample to the 1972-2000 period. The only finding that stands out is the fact that in OECD countries government consumption volatility tends to be higher when government size is large. The population coefficient ( $p o p)$ is only significant in the specification with institutional quality, and its interaction term with decentralization $\left(f d \_w b^{*} p o p\right)$, is negative and statistically significant only for non-OECD countries (however, coupled with the positive coefficient associated to $f d \_w b$, this results in no effects for average values of the variables). As for institutional quality, its coefficient is surprisingly positive but it is only significant at $10 \%$ level the OECD countries sub-sample, therefore it is hard to comment on this result.

Table 7, containing the estimates obtained with the OECD data sample, offers more interesting results. The specification with the population-decentralization interaction term ( $f d$ oecd*pop) yields negative and significant coefficients for both $f d \_o e c d$ and pop, while their interaction is estimated to be positive (even at $10 \%$ significance level). This means that fiscal decentralization combined with a large population may lead to an increase in government spending volatility. However, for reasonable values of the two variables the overall impact of both fiscal decentralization and country size is still negative, thus reinforcing the result obtained with the initial estimates.

The government size coefficient is found again (see the results in Table 6 for the OECD countries with $f d \_w b$ ) to be statistically different from zero and positive, while the decentralization coefficient remains negative and significant. Thus, government size increases consumption volatility only provided that a certain degree of development has been reached. This confirms the initial expectations (see Section 2) according to which a larger government size is likely to lead to higher consumption volatility. Finally, we do not find any result with regards to institutional quality, whose coefficient is estimated not to be significant and not affecting that associated to fiscal decentralization.

Overall, our additional estimates do not seem to support the importance of some channels, such as fiscal discipline acting on discretionary policy, or decentralization influencing institutional quality, through which fiscal decentralization may lower government consumption volatility. On the other hand, they highlight the influence of decentralization on the volatility of automatic stabilisers, given their connection with the central level of government. Moreover, it appears that government size is able to increase government consumption volatility independently from the degree of decentralization, but this effect works only in developed countries. All in all, our evidence implies that having spending and revenue competences spread within a multi-layered system can mitigate the volatility of government consumption.

\section{Concluding remarks}

In this paper we investigated the impact of fiscal decentralization on government consumption volatility controlling for a number of institutional, regional, demographic, and macroeconomic factors, as well as considering several potential transmission channels. Our contribution lies in the 
novel research question with respect to previous studies combined with the utilization of diverse data sources and large country coverage to ensure that results are not driven by the choice of specific decentralization indicators.

We found that higher degrees of fiscal decentralization lead to less volatile government consumption expenditure in more advances economies only (i.e. OECD countries). On the other hand, the same does not hold for less developed countries. Thus, it seems that in order to alleviate government consumption volatility fiscal decentralization may be implemented only provided that a minimum level of development has been reached.

The beneficial effect of fiscal decentralization on government consumption volatility persists even controlling for country size, which is also negatively related to such volatility, and for the interaction between the two. Thus, small countries appear to be more prone to excessive volatility of government expenditure, which may harm their fiscal stability perspectives. Reforming their institutional systems by giving more fiscal responsibility and competences to sub-central tiers of government can be a way to reduce volatility of public spending and, consequently, also their macroeconomic vulnerability. Large countries are normally the more fiscally decentralized ones; therefore, there is room for the smaller ones to benefit from implementing policies and institutional changes aimed at increasing their degree of fiscal decentralization.

Beyond this, the virtuous effect of fiscal decentralization on consumption volatility is strongest for the non-discretionary spending component, while it is absent for discretionary policy. Again, this mechanism tends to work in more developed countries only. This means that fiscal decentralization is more effective in mitigating government volatility by reducing the role of central governments - and of its typical instruments, i.e. the automatic stabilisers - than by increasing overall fiscal discipline which would likely limit room for discretionary fiscal measures.

No other potential channels appear to affect the relationship between fiscal decentralization and consumption volatility, with the exception of government size that seems to increase the latter regardless of the degree of decentralization. Therefore, a country willing to reduce its public consumption volatility may decide to increase fiscal decentralization which may result in lower aggregate government size with further benefits in terms of diminished volatility.

Overall, the fact that the result holds for OECD economies only seems to suggest that the virtuous effect of fiscal decentralization on government volatility can be obtained only provided that the country has achieved a minimum level of development, other things equal. We also know that nonOECD countries are less decentralized than OECD ones (on average, fiscal decentralization is $16 \%$ for the former group and $25 \%$ for the latter). This may also suggest that a certain level of fiscal decentralization within the country is required in order to effectively reduce government spending volatility. 


\section{References}

Afonso, A., Furceri, D. (2008). Government size, composition, volatility and economic growth. ECB Working Paper No. 849.

Afonso, A., Agnello, L., Furceri, D. (2010). Fiscal policy responsiveness, persistence, and discretion. Public Choice 145, 503-530.

Akai, N., Sakata, M. (2002). Fiscal decentralization contributes to economic growth: evidence from state-level cross-section data for the United States. Journal of Urban Economics 52, 93-108.

Alesina, A., Spolaore, E. (1997). On the Number and Size of Nations. Quarterly Journal of Economics $112,1027-56$.

Alesina, A., Wacziarg, R. (1998). Openness, country size and government. Journal of Public Economics 69(3), 305-321.

Allen, F., Gale, D. (1994). Limited market participation and volatility of asset prices. The American Economic Review 84(4), 933-955.

Andrés, J., Doménech, R., Fatás, A. (2008). The Stabilizing Role of Government Size. Journal of Economic Dynamics and Control 32(2), 571-593.

Arzaghi, M., Henderson, J.V. (2005). Why Countries Are Fiscally Decentralizing. Journal of Public Economics 89, 1157-1189.

Ashworth, J., Galli, E., Padovano, F. (2012). Decentralization as a constraint to Leviathan: a panel cointegration analysis. Public Choice, DOI 10.1007/s11127-012-9962-8.

Badinger, H. (2009). Fiscal rules, discretionary fiscal policy and macroeconomic stability: an empirical assessment for OECD countries. Applied Economics 41(7), 829-847.

Blinder, A., Solow, R. (1974). Analytical foundations of fiscal policy, in The Economics of Public Finance, Washington, D.C.: The Brookings Institution.

Blöchliger, H., Vammalle, C. (2012). Australia: the intergovernmental agreement on federal financial relations. In Reforming Fiscal Federalism and Local Government: Beyond the Zero-Sum Game. OECD Publishing.

Bodman, P., Hodge, A. (2010). What Drives Fiscal Decentralisation? Further Assessing the Role of Income. Fiscal Studies 31(3), 373-404.

Brennan, G., \& Buchanan, J. (1980). The power to tax: analytical foundations of a fiscal constitution. Cambridge: Cambridge University Press.

Breton, A. (1987). Towards a theory of competitive federalism. European Journal of Political Economy 3(1-2), 263-329.

Cassette, A., Paty, S. (2010). Fiscal decentralisation and the size of government: a European country empirical analysis. Public Choice 143(1-2), 173-189.

Coles, L., Beck, W. (2001). Distributed generation can provide an appropriate customer price response to help fix wholesale price volatility. IEEE Power Eng. Soc. Winter Meeting 1, 141-143. 
Dabla-Norris, E. (2006). The challenge of fiscal decentralisaton in transition countries. Comparative Economic Studies 48, 100-131.

Debrun, X., Pisani-Ferry, J., Sapir, A. (2008). Government Size and Output Volatility: Should We Forsake Automatic Stabilization? IMF Working Paper 122.

Demirgüç-Kunt, A., Levine, R. (1996). Stock markets, corporate finance, and economic growth: an overview. The World Bank Economic Review 10(2), 223-239.

Dziobek, C., Gutierrez Mangas, C., Kufa, P. (2011). Measuring fiscal decentralization - Exploring the IMF-s databases. IMF Working Paper 126.

Escolano, J., Eyraud, L., Badia, M.M., Sarnes, J., Tuladhar, A. (2012). Fiscal Performance, Institutional Design and Decentralization in European Union Countries. IMF Working Paper 145.

Ezcurra, R., Rodriguez-Pose, A. (2011). Is fiscal decentralization harmful for economic growth? Evidence from the OECD countries. Journal of Economic Geography 10, 619-644.

Fatas, A., Mihov, I. (2001). Government size and automatic stabilisers: international and intranational evidence. Journal of International Economics 55(1), 3-28.

Fatas, A., Mihov, I. (2003). The case for restricting fiscal policy discretion. Quarterly Journal of Economics 118, 1419-1447.

Fatas, A., Mihov, I. (2005). Policy volatility, institutions and economic growth. CEPR Discussion Paper 5388.

Fisman, R., Gatti, R. (2002). Decentralization and corruption: evidence across countries. Journal of Public Economics 83(3), 325-345.

Fiva, J.H. (2006). New Evidence on the Effect of Fiscal Decentralisation on the Size and Composition of Government Spending. FinanzArchiv 62(2), 250-280.

Furceri, D. (2007). Is government expenditure volatility harmful for growth? A cross-country analysis. Fiscal Studies 28(1), 103-120.

Furceri, D., Karras, G. (2008). Business cycle volatility and country size: evidence for a sample of OECD countries. Economics Bulletin 5(3), 1-7.

Furceri, D., Ribeiro, M.P. (2009). Government consumption volatility and the size of nations. OECD Working Paper No. 28.

Garrett, G., Rodden, J. (2003). Globalization and fiscal decentralization, in M. Kahler and D. A. Lake (Eds.), Governance in a Global Economy: Political Authority in Transition, Princeton, Princeton University Press, 87-109.

Gemmell, N., Kneller, R., Sanz, I. (2013). Fiscal Decentralization and Economic Growth: Spending versus Revenue Decentralization. Economic Inquiry 51(4), 1915-1931.

Jin, J., Zou, H. (2002), How does fiscal decentralisation affect aggregate, national, and subnational government size. Journal of Urban Economics 52, 270-293.

King, D., Ma, Y. (2001). Fiscal decentralization, central bank independence and inflation. Economic Letters 72, 95-98. 
Kyriacou, A.P, Roca-Sagalés, O. (2011). Fiscal Decentralisation and the Quality of Government in the OECD. Economics Letters 111(3), 191-193.

Letelier, L. (2005). Explaining Fiscal Decentralization. Public Finance Review 33(2), 155-183.

Liberati, P., Sacchi, A. (2012). Tax decentralization and local government size. Public Choice, DOI 10.1007/s11127-012-9937-9.

Loayza, Norman V., et al. Macroeconomic volatility and welfare in developing countries: an introduction. The World Bank Economic Review 21(3), 343-357.

Marlow, M. (1988). Fiscal decentralization and government size. Public Choice, 56(3), 259-269.

Martinez-Vazquez, J., McNab, R.M. (2003). Fiscal decentralization and economic growth. World Development 31, 1597-1616.

Musgrave, R.A. (1959). The theory of public finance: a study in public economy. New York: McGraw-Hill.

Neyapti, B. (2010). Fiscal decentralization and deficits: International evidence. European Journal of Political Economy 26, 155-166.

Nishimura, Y. (2006). Human fallibility, complementarity, and fiscal decentralization. Journal of Public Economic Theory 8(3), 487-501.

OECD, (2012). Decentralisation and economic growth. Network on Fiscal Relations Across Levels of Government, Paris.

Pagano, M. (1989). Endogenous market thinness and stock price volatility. The Review of Economic Studies 56(2), 269-287.

Panizza, U. (1999). On the Determinants of Fiscal Centralization: Theory and Evidence. Journal of Public Economics 74(1), 97-139.

Prohl, S., Schneider, F. (2009), Does Decentralisation Reduce Government Size? A Quantitative Study of the Decentralisation Hypothesis. Public Finance Review 37(6), 639-664.

Qian, Y., Weingast, B.R. (1997). Federalism as a Commitment to Perserving Market Incentives. The Journal of Economic Perspectives 11(4), 83-92.

Ravn, M.O., Uhlig, H. (2002). On adjusting the Hodrick-Prescott filter for the frequency of observations. Review of Economics and Statistics 84, 371-380.

Rodden, J. (2003). Reviving Leviathan: fiscal federalism and the growth of government. Industrial Organization 57(4), 695-729.

Rose, A.K. (2006). Size really doesn't matter: in search of a national scale effect. Journal of the Japanese and International Economies 20(4), 482-507.

Sacchi, A., Salotti, S. (2013). The effects of fiscal decentralization on household income inequality: some empirical evidence. Spatial Economic Analysis, forthcoming.

Salmon, P. (1987). Decentralization as an incentive scheme. Oxford Review of Economic Policy 3(2), $24-43$. 
Shadbegian, R. J. (1999). Fiscal federalism, collusion, and government size: evidence from the states.

Public Finance Review 27(3), 262-281.

Sepulveda, C.F., Martinez-Vazquez, J. (2011). The consequences of fiscal decentralization on poverty and income equality. Environment and Planning C: Government and Policy 29, 321-343.

Shelton, C.A. (2007). The Size and Composition of Government Expenditure. Journal of Public Economics 91(11-12), 2230-2260.

Spolaore, E. (2008). National Borders and the Size of Nations. In The Oxford Handbook of Political Economy, edited by B. Weingast and D. Wittman, 778-98, Oxford, UK: Oxford University Press.

Stegarescu, D. (2005). Public Sector Decentralisation: Measurement Concepts and Recent International Trends. Fiscal Studies 26(3), 301-333.

Stegarescu, D. (2009). The Effects of Economic and Political Integration on Fiscal Decentralisation: Evidence from OECD Countries. Canadian Journal of Economics 42(2), 694-718.

Ter-Minassian, T. (1997). Fiscal Federalism in Theory and Practice. International Monetary Fund, Washington D.C.

Thieben, U., (2003). Fiscal decentralization and economic growth in high-income OECD countries. Fiscal Studies 24(3), 237-274.

Thornton, J. (2007). Fiscal decentralization and economic growth reconsidered. Journal of Urban Economics 61(1), 64-70. 


\section{Figures and tables}

Figure 1: Evolution of fiscal decentralization (WB data)

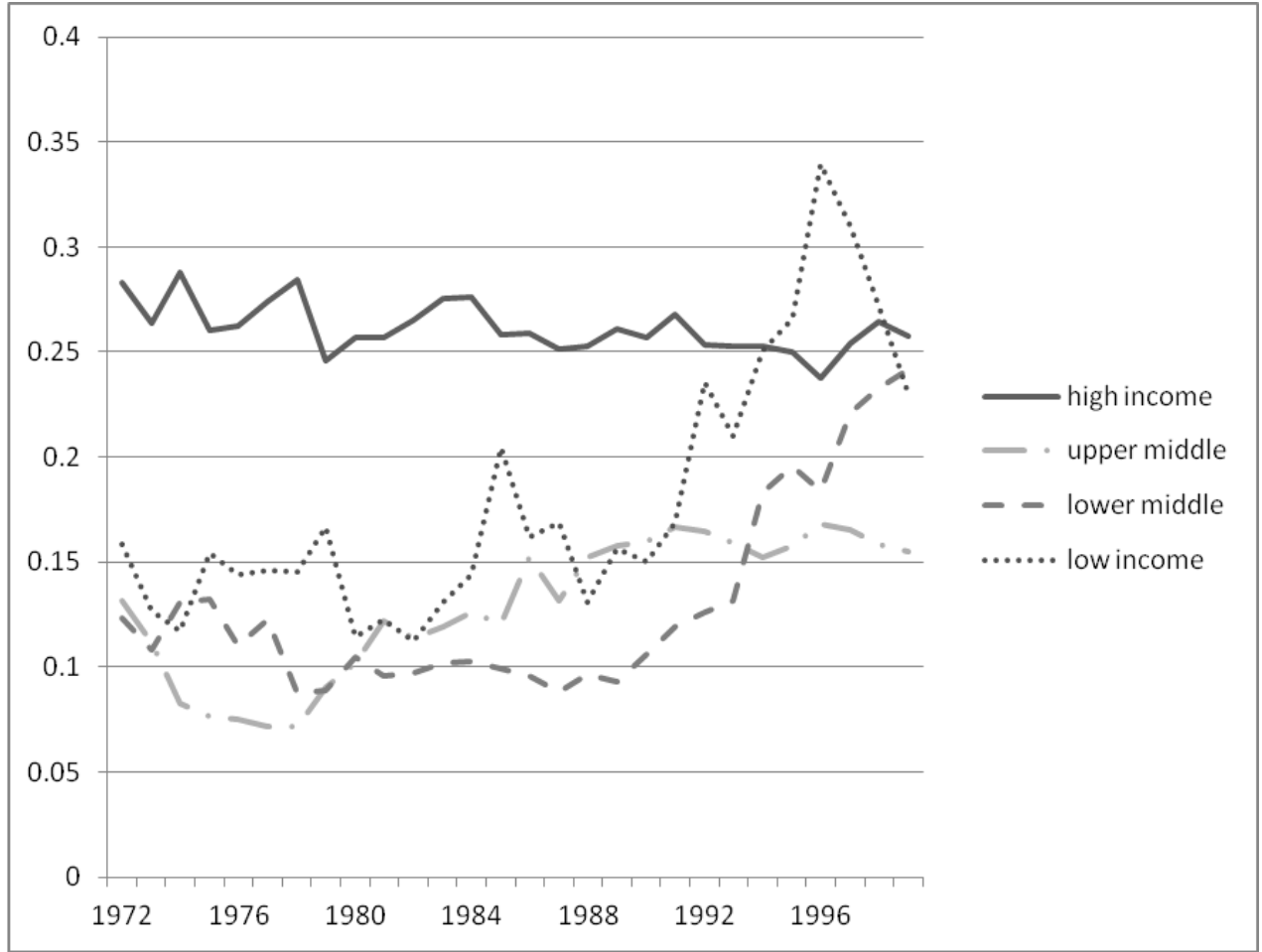

Source: Authors' elaborations.

Figure 2: Government consumption volatility and fiscal decentralization (WB data)

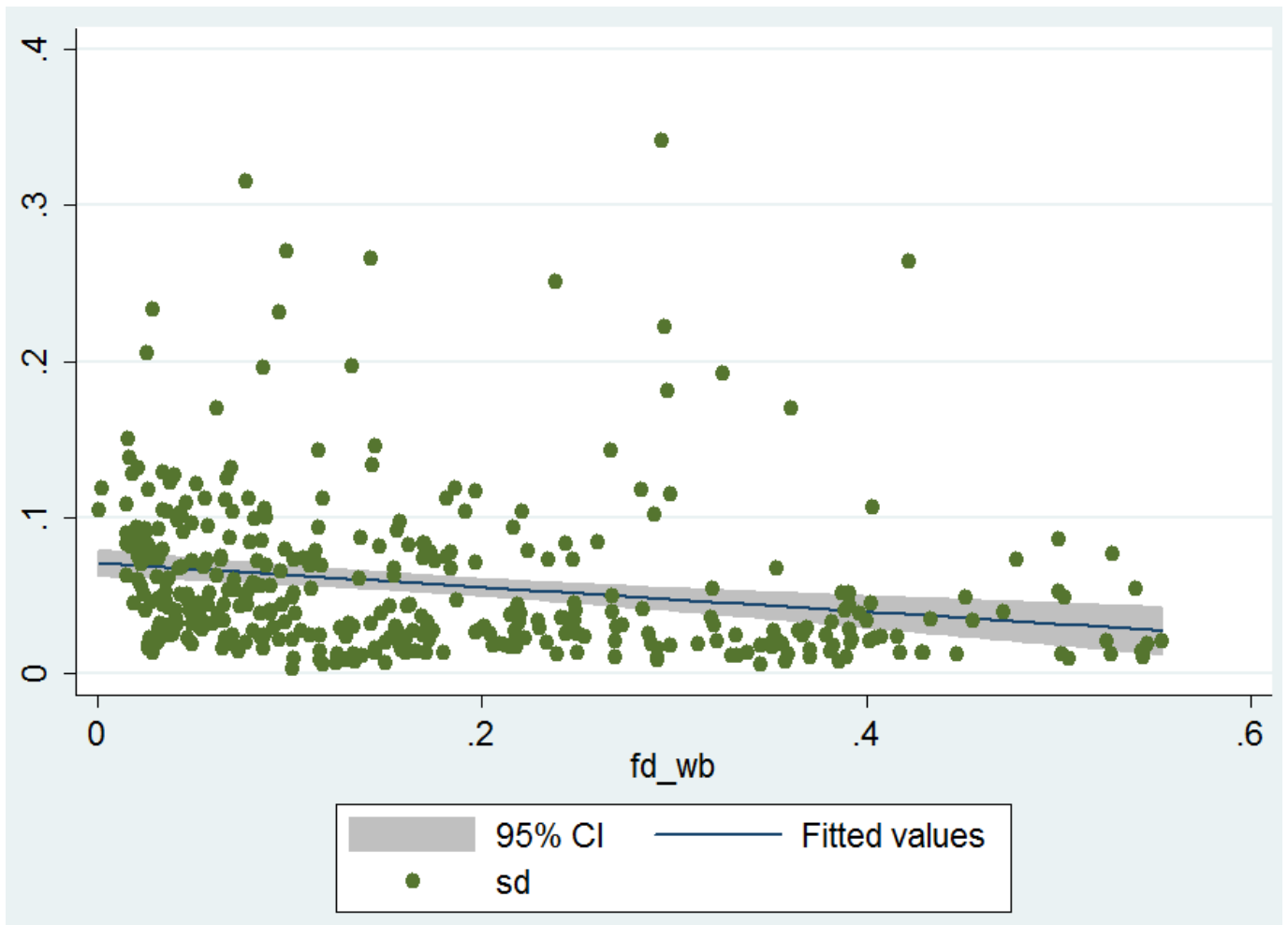

Source: Authors' elaborations. 
Figure 3: Government consumption volatility and fiscal decentralization (OECD data)

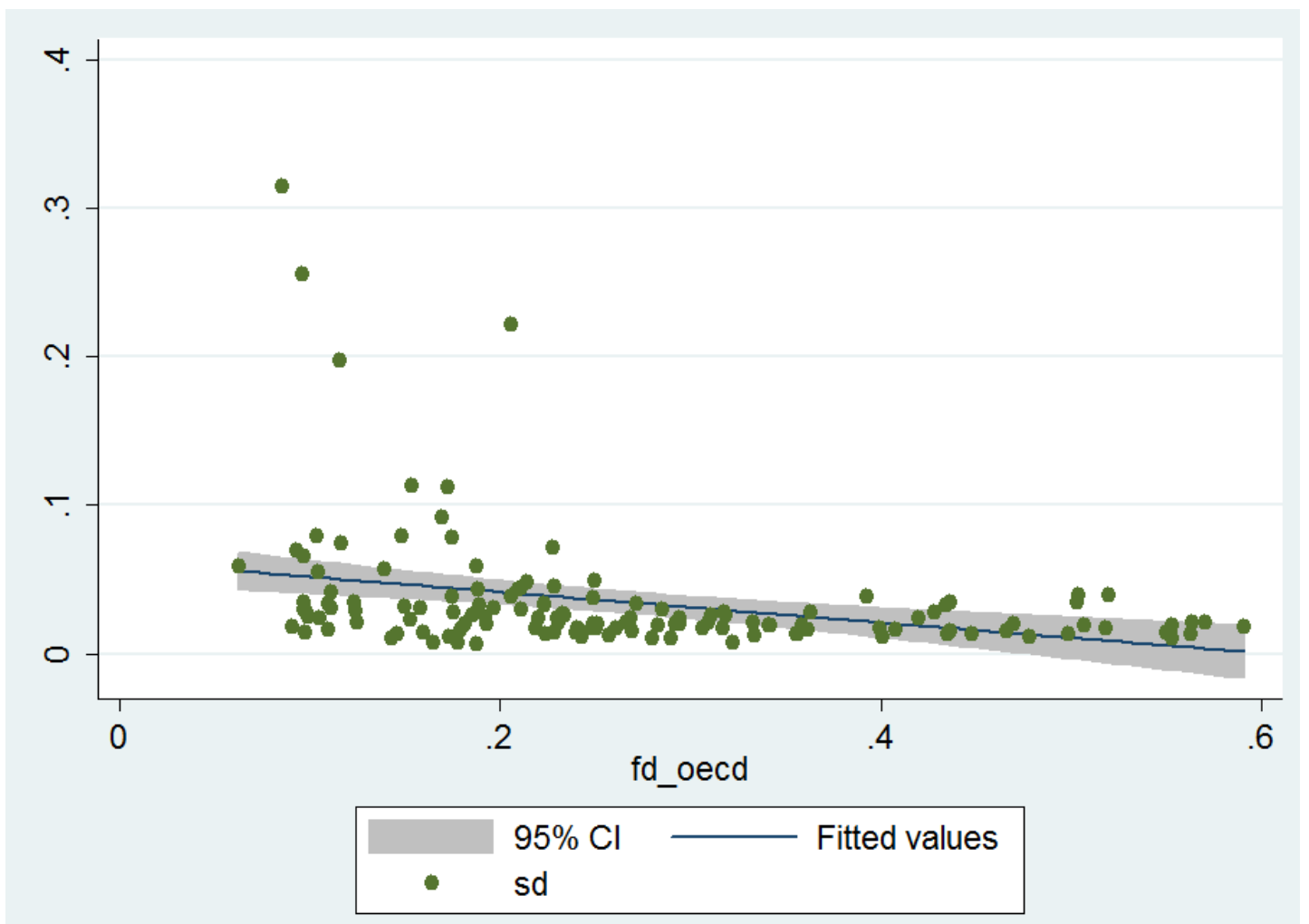

Source: Authors' elaborations.

Figure 4: Correlation between fiscal decentralization (OECD data) and country size

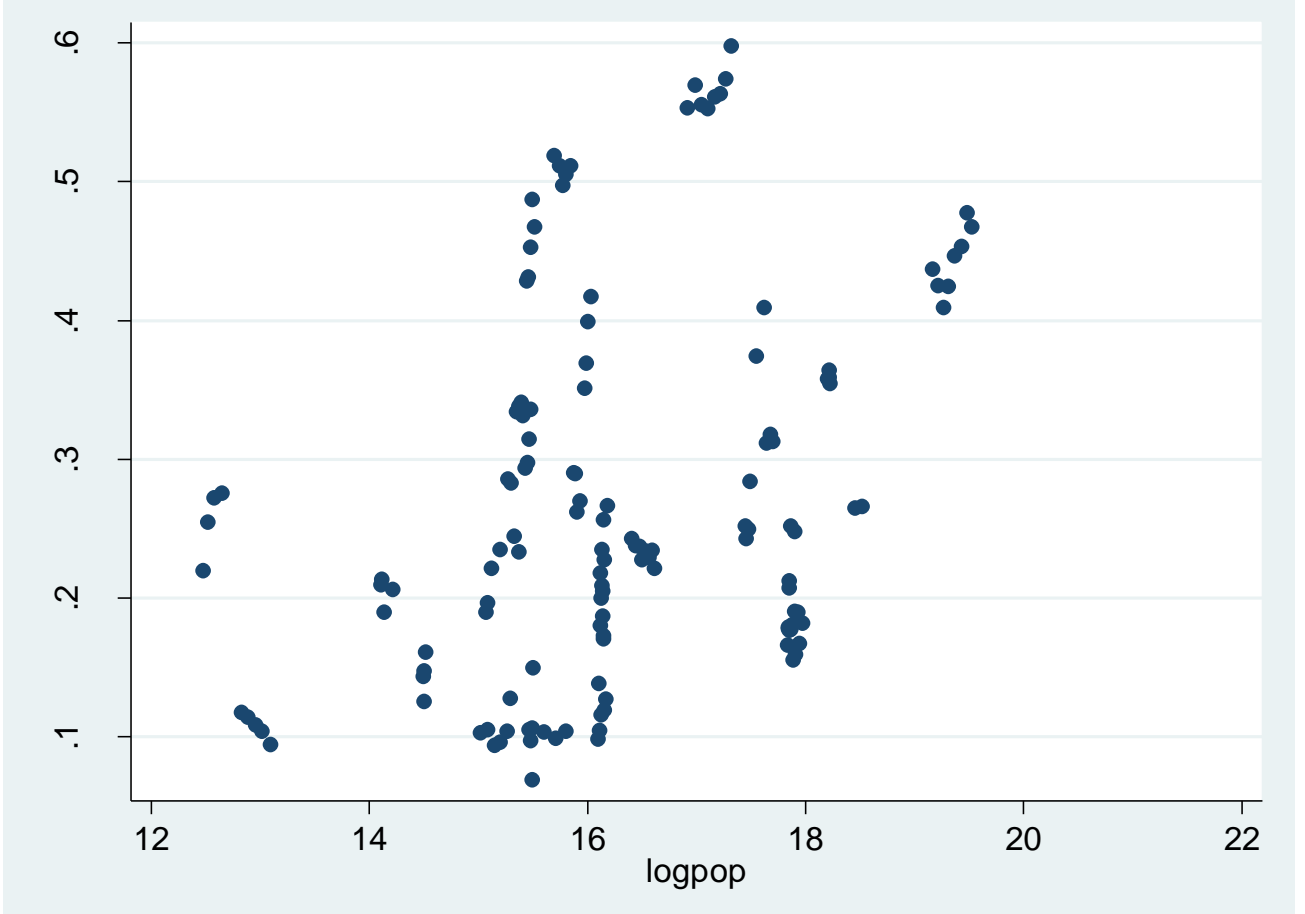

Source: Authors' elaborations. 
Table 1: Pairwise correlations between government consumption volatility and fiscal decentralization

\begin{tabular}{|l|l|}
\hline$e d \_w b$ & $-0.18^{* *}$ \\
$r d \_w b$ & $-0.13^{*}$ \\
$f d \_w b$ & $-0.16^{* *}$ \\
$e d \_o e c d$ & $-0.36^{* *}$ \\
$r d \_o e c d$ & $-0.28^{* *}$ \\
fd_oecd & $-0.34 * *$ \\
\hline
\end{tabular}

Notes: ** and * indicate statistical significance at 1 and $5 \%$ respectively. 
Table 2: Model (1) (four specifications), WB data sample and two sub-samples

\begin{tabular}{|c|c|c|c|c|c|c|c|c|c|c|c|c|}
\hline \multirow[b]{2}{*}{ Specification: } & \multicolumn{4}{|c|}{ All countries } & \multicolumn{4}{|c|}{ OECD countries } & \multicolumn{4}{|c|}{ Non-OECD countries } \\
\hline & A & B & $\mathrm{C}$ & $\mathrm{D}$ & A & B & $\mathrm{C}$ & $\mathrm{D}$ & A & B & $\mathrm{C}$ & $\mathrm{D}$ \\
\hline$f d \_w b$ & $\begin{array}{c}-7.85 * * * \\
(2.99) \\
\end{array}$ & $\begin{array}{l}0.056 \\
(4.59)\end{array}$ & $\begin{array}{c}0.89 \\
(4.59)\end{array}$ & $\begin{array}{c}1.84 \\
(5.36)\end{array}$ & $\begin{array}{c}-7.87 * * \\
(2.99)\end{array}$ & $\begin{array}{l}-2.08 \\
(2.87)\end{array}$ & $\begin{array}{l}-5.68 \\
(4.32)\end{array}$ & $\begin{array}{l}-0.55 \\
(3.54)\end{array}$ & \begin{tabular}{|c|}
2.45 \\
$(5.68)$ \\
\end{tabular} & $\begin{array}{l}-0.27 \\
(6.26)\end{array}$ & $\begin{array}{c}3.15 \\
(7.00)\end{array}$ & $\begin{array}{l}-0.14 \\
(8.06)\end{array}$ \\
\hline landl & & $\begin{array}{c}1.08 \\
(1.40)\end{array}$ & $\begin{array}{c}0.69 \\
(1.60)\end{array}$ & $\begin{array}{c}1.01 \\
(1.86)\end{array}$ & & $\begin{array}{c}0.73 \\
(1.81)\end{array}$ & $\begin{array}{l}-1.83 \\
(2.65)\end{array}$ & $\begin{array}{l}-0.50 \\
(1.75)\end{array}$ & & $\begin{array}{c}1.79 \\
(1.81)\end{array}$ & $\begin{array}{c}1.41 \\
(1.75)\end{array}$ & $\begin{array}{c}2.11 \\
(1.71)\end{array}$ \\
\hline island & & $\begin{array}{c}0.94 \\
(1.06)\end{array}$ & $\begin{array}{l}-1.21 \\
(1.41)\end{array}$ & $\begin{array}{l}-0.66 \\
(1.62)\end{array}$ & & $\begin{array}{c}0.54 \\
(0.60)\end{array}$ & $\begin{array}{l}-3.05^{*} \\
(1.55)\end{array}$ & $\begin{array}{l}0.27 \\
(2.97)\end{array}$ & & $\begin{array}{l}2.37^{*} \\
(1.36)\end{array}$ & $\begin{array}{l}-0.17 \\
(1.83)\end{array}$ & $\begin{array}{l}-1.37 \\
(2.15)\end{array}$ \\
\hline latm & & $\begin{array}{c}0.021 \\
(0.033)\end{array}$ & $\begin{array}{c}0.012 \\
(0.040)\end{array}$ & $\begin{array}{c}0.011 \\
(0.042)\end{array}$ & & $\begin{array}{c}0.038 \\
(0.050)\end{array}$ & $\begin{array}{c}0.061 \\
(0.051)\end{array}$ & $\begin{array}{c}0.073 \\
(0.056)\end{array}$ & & $\begin{array}{c}-0.0020 \\
(0.051)\end{array}$ & $\begin{array}{l}-0.036 \\
(0.052)\end{array}$ & $\begin{array}{l}-0.055 \\
(0.050)\end{array}$ \\
\hline income_2 & & $\begin{array}{c}0.97 \\
(1.40)\end{array}$ & $\begin{array}{l}2.37^{*} \\
(1.41)\end{array}$ & $\begin{array}{c}1.16 \\
(2.29)\end{array}$ & & $\begin{array}{l}4.08 \\
(2.43)\end{array}$ & $\begin{array}{l}5.33 * \\
(2.70)\end{array}$ & $\begin{array}{l}3.57 \\
(2.28)\end{array}$ & & $\begin{array}{c}2.83 \\
(1.72)\end{array}$ & $\begin{array}{l}5.09 * * \\
(2.27)\end{array}$ & $\begin{array}{c}5.13 \\
(3.42)\end{array}$ \\
\hline income_3 & & $\begin{array}{c}2.88 * * * * \\
(1.06)\end{array}$ & $\begin{array}{c}5.72 * * * \\
(1.61)\end{array}$ & $\begin{array}{l}4.56^{*} \\
(2.61)\end{array}$ & & & & & & $\begin{array}{c}3.87 * * * \\
(1.23)\end{array}$ & $\begin{array}{c}8.30 * * * * \\
(2.56)\end{array}$ & $\begin{array}{l}8.06^{*} \\
(4.08)\end{array}$ \\
\hline income_4 & & $\begin{array}{c}7.78^{* * * *} \\
(1.92)\end{array}$ & $\begin{array}{c}11.3 * * * \\
(2.52)\end{array}$ & $\begin{array}{l}7.81^{*} \\
(3.99)\end{array}$ & & & & & & $\begin{array}{c}9.54 * * * \\
(2.62)\end{array}$ & $\begin{array}{c}14.3 * * * \\
(3.73)\end{array}$ & $\begin{array}{l}11.5^{*} \\
(5.82)\end{array}$ \\
\hline opec & & $\begin{array}{c}2.59 \\
(1.96)\end{array}$ & $\begin{array}{c}3.61 * * \\
(1.76)\end{array}$ & $\begin{array}{c}3.34 \\
(2.13)\end{array}$ & & & & & & $\begin{array}{c}1.46 \\
(2.48)\end{array}$ & $\begin{array}{c}2.73 \\
(2.46)\end{array}$ & $\begin{array}{l}1.87 \\
(2.92)\end{array}$ \\
\hline comecon & & $\begin{array}{c}7.99 * * * \\
(2.96)\end{array}$ & $\begin{array}{c}6.73 * * \\
(2.84)\end{array}$ & $\begin{array}{c}8.69 * * \\
(3.70)\end{array}$ & & $\begin{array}{c}2.70 \\
(2.89)\end{array}$ & $\begin{array}{c}3.41 \\
(2.93)\end{array}$ & $\begin{array}{c}2.17 \\
(2.42)\end{array}$ & & $\begin{array}{c}9.49 * * \\
(4.70)\end{array}$ & $\begin{array}{c}6.82 \\
(4.46)\end{array}$ & $\begin{array}{l}14.7 * * \\
(5.90)\end{array}$ \\
\hline independence & & $\begin{array}{c}0.0011 \\
(0.00072)\end{array}$ & $\begin{array}{c}0.00047 \\
(0.00094)\end{array}$ & $\begin{array}{l}0.00037 \\
(0.0011) \\
\end{array}$ & & $\begin{array}{c}0.00056 \\
(0.00090)\end{array}$ & $\begin{array}{l}0.00035 \\
(0.0014)\end{array}$ & $\left\{\begin{array}{l}-0.00029 \\
(0.00088)\end{array}\right.$ & & $\begin{array}{c}0.0018 \\
(0.0014)\end{array}$ & $\begin{array}{l}0.00035 \\
(0.0015)\end{array}$ & $\begin{array}{l}-0.0013 \\
(0.0012)\end{array}$ \\
\hline $\begin{array}{l}\text { pop } \\
\text { urban } \\
\text { pop_dens }\end{array}$ & & & \begin{tabular}{|c|}
$-0.80^{* *}$ \\
$(0.35)$ \\
$0.069^{*}$ \\
$(0.035)$ \\
0.0073 \\
$(0.0067)$ \\
\end{tabular} & $\begin{array}{c}-0.41 \\
(0.33) \\
0.073 \\
(0.045) \\
0.0071 \\
(0.0082)\end{array}$ & & & $\begin{array}{c}-0.74 * * \\
(0.33) \\
0.059 \\
(0.041) \\
-0.0052 \\
(0.0054) \\
\end{array}$ & $\begin{array}{c}0.27 \\
(0.55) \\
0.060 \\
(0.064) \\
-0.012 \\
(0.0085) \\
\end{array}$ & & & $\begin{array}{c}-1.20^{* *} \\
(0.59) \\
0.089^{*} \\
(0.048) \\
0.0086 \\
(0.0080)\end{array}$ & $\begin{array}{c}-1.04 * \\
(0.57) \\
0.086 \\
(0.052) \\
0.015 \\
(0.0095)\end{array}$ \\
\hline $\begin{array}{l}\text { gdp } \\
\text { inflation } \\
\text { open } \\
\text { fin_open } \\
\text { fin_depth }\end{array}$ & & & & \begin{tabular}{|c|}
-0.91 \\
$(1.39)$ \\
$0.0042 * * *$ \\
$(0.0012)$ \\
0.017 \\
$(0.021)$ \\
$-1.6 \mathrm{e}-06$ \\
$(4.4 \mathrm{e}-06)$ \\
0.28 \\
$(1.37)$
\end{tabular} & & & & \begin{tabular}{|c|}
-2.31 \\
$(1.86)$ \\
-0.021 \\
$(0.031)$ \\
0.040 \\
$(0.042)$ \\
$4.5 \mathrm{e}-06$ \\
$(3.3 \mathrm{e}-06)$ \\
1.32 \\
$(0.93)$
\end{tabular} & & & & $\begin{array}{c}-0.41 \\
(1.59) \\
0.0039 * * * \\
(0.0011) \\
0.0045 \\
(0.023) \\
-4.7 \mathrm{e}-05 \\
(2.9 \mathrm{e}-05) \\
0.72 \\
(1.63)\end{array}$ \\
\hline $\begin{array}{l}\text { Observations } \\
\text { R-squared }\end{array}$ & $\begin{array}{c}372 \\
0.046\end{array}$ & $\begin{array}{c}372 \\
0.312\end{array}$ & $\begin{array}{c}361 \\
0.338\end{array}$ & $\begin{array}{c}329 \\
0.382\end{array}$ & $\begin{array}{c}143 \\
0.141\end{array}$ & $\begin{array}{c}143 \\
0.451\end{array}$ & $\begin{array}{c}132 \\
0.542\end{array}$ & $\begin{array}{c}127 \\
0.552\end{array}$ & $\begin{array}{c}229 \\
0.032\end{array}$ & $\begin{array}{c}229 \\
0.271\end{array}$ & $\begin{array}{c}229 \\
0.307\end{array}$ & $\begin{array}{c}202 \\
0.406\end{array}$ \\
\hline
\end{tabular}

Note: robust clustered standard errors in parentheses. $* * *, * *, *$ denote significance at $1 \%, 5 \%$, and $10 \%$ respectively. A constant, period, and language dummies (the latter in specifications B, C, and D only) are included but not reported for the sake of brevity. 
Table 3: Model (1) (four specifications), OECD data sample

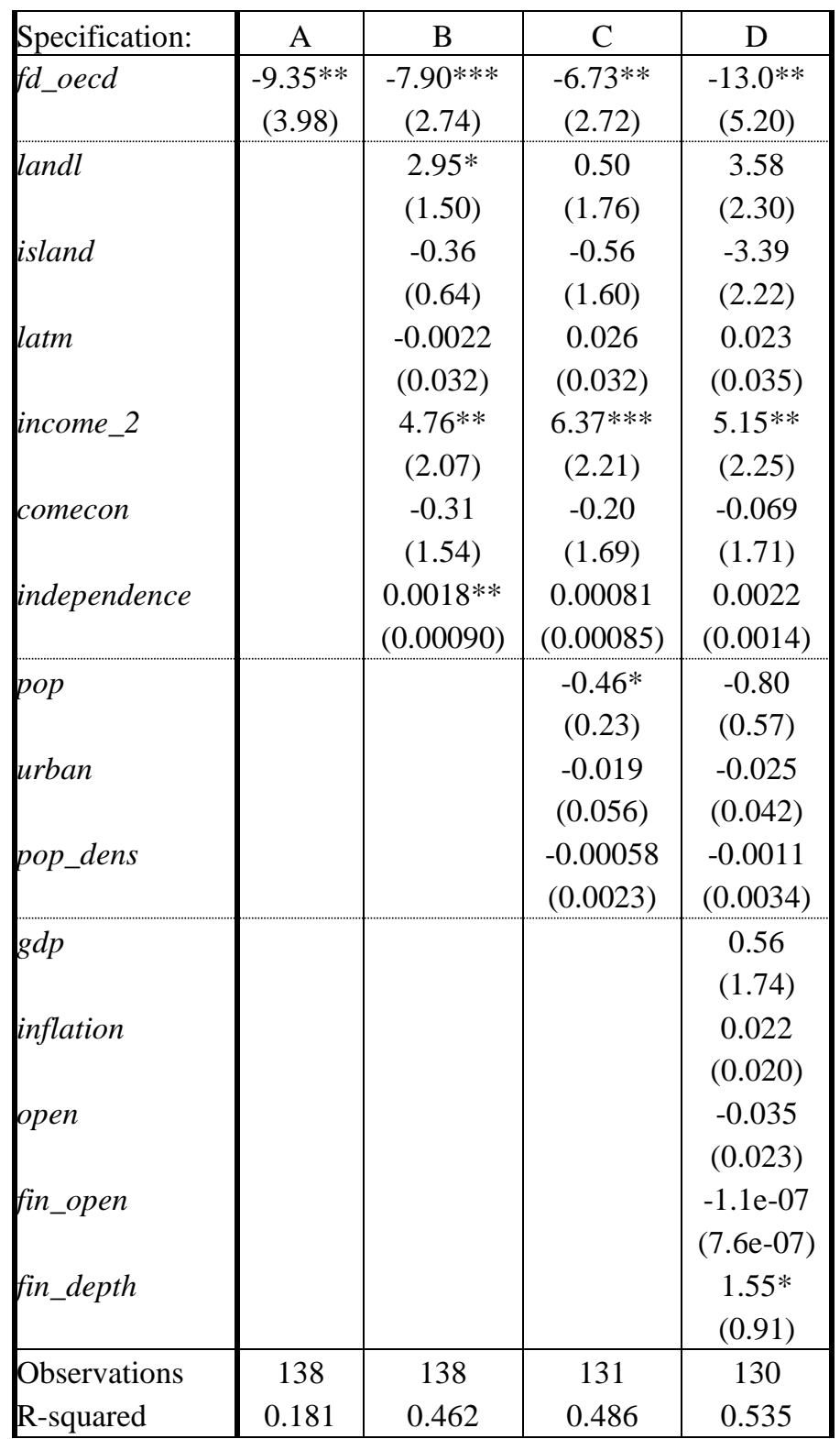

Note: robust clustered standard errors in parentheses. ***, **, * denote significance at $1 \%, 5 \%$, and $10 \%$ respectively. A constant, period, and language dummies (the latter in specifications B, C, and D only) are included but not reported for the sake of brevity. 
Table 4: Model (1), automatic and discretionary consumption volatility, WB data sample and two sub-samples

\begin{tabular}{|c|c|c|c|c|c|c|}
\hline \multirow[b]{2}{*}{ Specification: } & \multicolumn{2}{|c|}{ All countries } & \multicolumn{2}{|c|}{ OECD countries } & \multicolumn{2}{|c|}{ Non-OECD countries } \\
\hline & Discretionary & Automatic & Discretionary & Automatic & Discretionary & Automatic \\
\hline$f d \_w b$ & $\begin{array}{c}29.3 \\
(24.2)\end{array}$ & $\begin{array}{c}32.1 \\
(25.4)\end{array}$ & $\begin{array}{l}-4.99 \\
(3.25)\end{array}$ & $\begin{array}{c}-6.00 * * * \\
(1.88)\end{array}$ & $\begin{array}{c}21.2 \\
(24.3)\end{array}$ & $\begin{array}{c}19.5 \\
(25.5)\end{array}$ \\
\hline landl & $\begin{array}{c}6.85 \\
(6.77)\end{array}$ & $\begin{array}{c}6.03 \\
(7.13)\end{array}$ & $\begin{array}{l}-0.13 \\
(2.24)\end{array}$ & $\begin{array}{l}-1.43 \\
(0.92)\end{array}$ & $\begin{array}{c}14.2 \\
(10.2)\end{array}$ & $\begin{array}{c}14.5 \\
(10.5)\end{array}$ \\
\hline island & $\begin{array}{c}3.98 \\
(4.33)\end{array}$ & $\begin{array}{c}4.79 \\
(4.64)\end{array}$ & $\begin{array}{c}0.49 \\
(2.66)\end{array}$ & $\begin{array}{l}-0.77 \\
(1.15)\end{array}$ & $\begin{array}{c}3.89 \\
(6.36)\end{array}$ & $\begin{array}{c}5.74 \\
(6.95)\end{array}$ \\
\hline latm & $\begin{array}{c}0.30 \\
(0.30)\end{array}$ & $\begin{array}{c}0.28 \\
(0.32)\end{array}$ & $\begin{array}{c}0.047 \\
(0.062)\end{array}$ & $\begin{array}{c}0.033 \\
(0.020)\end{array}$ & $\begin{array}{c}0.53 \\
(0.58)\end{array}$ & $\begin{array}{c}0.54 \\
(0.60)\end{array}$ \\
\hline income_2 & $\begin{array}{l}-17.6 \\
(14.5)\end{array}$ & $\begin{array}{l}-19.5 \\
(15.2)\end{array}$ & $\begin{array}{c}1.33 \\
(1.66)\end{array}$ & $\begin{array}{c}0.53 \\
(0.98)\end{array}$ & $\begin{array}{l}-12.4 \\
(20.0)\end{array}$ & $\begin{array}{l}-10.8 \\
(20.6)\end{array}$ \\
\hline income_3 & $\begin{array}{l}-7.21 \\
(11.3)\end{array}$ & $\begin{array}{l}-7.63 \\
(11.8)\end{array}$ & & & $\begin{array}{l}-9.07 \\
(21.9)\end{array}$ & $\begin{array}{l}-6.53 \\
(22.9)\end{array}$ \\
\hline income_4 & $\begin{array}{l}-19.6 \\
(26.0)\end{array}$ & $\begin{array}{l}-18.6 \\
(27.4)\end{array}$ & & & $\begin{array}{l}-24.0 \\
(39.4)\end{array}$ & $\begin{array}{l}-18.5 \\
(41.2)\end{array}$ \\
\hline opec & $\begin{array}{c}5.19 \\
(7.86)\end{array}$ & $\begin{array}{c}5.08 \\
(8.16)\end{array}$ & & & $\begin{array}{c}6.31 \\
(10.5)\end{array}$ & $\begin{array}{c}5.35 \\
(10.9)\end{array}$ \\
\hline comecon & $\begin{array}{l}32.7 * \\
(17.6)\end{array}$ & $\begin{array}{l}35.3 * \\
(18.5)\end{array}$ & $\begin{array}{l}3.38 * \\
(1.85)\end{array}$ & $\begin{array}{l}2.08 * \\
(1.03)\end{array}$ & $\begin{array}{l}60.2 * \\
(34.4)\end{array}$ & $\begin{array}{l}65.7 * \\
(35.9)\end{array}$ \\
\hline independence & $\begin{array}{c}0.0033 \\
(0.0034)\end{array}$ & $\begin{array}{c}0.0029 \\
(0.0036)\end{array}$ & $\begin{array}{r}-0.000039 \\
(0.00093)\end{array}$ & $\begin{array}{c}-0.00054 \\
(0.00064)\end{array}$ & $\begin{array}{c}0.0033 \\
(0.0048)\end{array}$ & $\begin{array}{c}0.0027 \\
(0.0051)\end{array}$ \\
\hline pop & $\begin{array}{c}0.17 \\
(1.13)\end{array}$ & $\begin{array}{c}0.45 \\
(1.20)\end{array}$ & $\begin{array}{c}0.33 \\
(0.58)\end{array}$ & $\begin{array}{c}0.12 \\
(0.25)\end{array}$ & $\begin{array}{c}0.97 \\
(1.93)\end{array}$ & $\begin{array}{c}1.34 \\
(2.03)\end{array}$ \\
\hline urban & $\begin{array}{c}0.17 \\
(0.18)\end{array}$ & $\begin{array}{c}0.19 \\
(0.19)\end{array}$ & $\begin{array}{l}-0.0029 \\
(0.071)\end{array}$ & $\begin{array}{c}-0.0038 \\
(0.028)\end{array}$ & $\begin{array}{l}0.045 \\
(0.20)\end{array}$ & $\begin{array}{l}0.067 \\
(0.19)\end{array}$ \\
\hline pop_dens & $\begin{array}{c}-0.00076 \\
(0.011)\end{array}$ & $\begin{array}{c}0.000016 \\
(0.012)\end{array}$ & $\begin{array}{l}-0.0085 \\
(0.0093)\end{array}$ & $\begin{array}{c}-0.0098 * * * \\
(0.0029)\end{array}$ & $\begin{array}{l}0.0094 \\
(0.015)\end{array}$ & $\begin{array}{c}0.010 \\
(0.016)\end{array}$ \\
\hline$g d p$ & $\begin{array}{l}-12.2 \\
(10.9)\end{array}$ & $\begin{array}{l}-12.4 \\
(11.5)\end{array}$ & $\begin{array}{l}-0.59 \\
(2.26)\end{array}$ & $\begin{array}{l}-0.60 \\
(0.74)\end{array}$ & $\begin{array}{l}-9.67 \\
(11.3)\end{array}$ & $\begin{array}{l}-8.65 \\
(11.7)\end{array}$ \\
\hline inflation & $\begin{array}{l}0.0039 * \\
(0.0020)\end{array}$ & $\begin{array}{c}0.0017 \\
(0.0020)\end{array}$ & $\begin{array}{l}0.0052 \\
(0.025)\end{array}$ & $\begin{array}{l}0.026 * * \\
(0.0093)\end{array}$ & $\begin{array}{l}0.0068 * \\
(0.0035)\end{array}$ & $\begin{array}{c}0.0043 \\
(0.0035)\end{array}$ \\
\hline open & $\begin{array}{c}0.083 \\
(0.061)\end{array}$ & $\begin{array}{c}0.090 \\
(0.064)\end{array}$ & $\begin{array}{c}0.028 \\
(0.046)\end{array}$ & $\begin{array}{l}0.0018 \\
(0.011)\end{array}$ & $\begin{array}{c}0.055 \\
(0.079)\end{array}$ & $\begin{array}{c}0.047 \\
(0.084)\end{array}$ \\
\hline fin_open & $\begin{array}{c}1.3 \mathrm{e}-05 \\
(1.4 \mathrm{e}-05)\end{array}$ & $\begin{array}{c}1.1 \mathrm{e}-05 \\
(1.3 \mathrm{e}-05)\end{array}$ & $\begin{array}{c}3.9 \mathrm{e}-06 \\
(2.5 \mathrm{e}-06)\end{array}$ & $\begin{array}{c}1.0 \mathrm{e}-06 \\
(9.5 \mathrm{e}-07)\end{array}$ & $\begin{array}{l}-4.9 e-05 \\
(6.1 e-05)\end{array}$ & $\begin{array}{l}-5.2 \mathrm{e}-05 \\
(6.1 \mathrm{e}-05)\end{array}$ \\
\hline fin_depth & $\begin{array}{l}-10.1 \\
(7.26)\end{array}$ & $\begin{array}{l}-10.7 \\
(7.43)\end{array}$ & $\begin{array}{c}0.22 \\
(1.15) \\
\end{array}$ & $\begin{array}{c}0.16 \\
(0.35) \\
\end{array}$ & $\begin{array}{l}-14.2 \\
(9.73)\end{array}$ & $\begin{array}{c}-14.2 \\
(10.00)\end{array}$ \\
\hline $\begin{array}{l}\text { Observations } \\
\text { R-squared }\end{array}$ & $\begin{array}{c}319 \\
0.229\end{array}$ & $\begin{array}{c}319 \\
0.225 \\
\end{array}$ & $\begin{array}{c}123 \\
0.497 \\
\end{array}$ & $\begin{array}{c}123 \\
0.651 \\
\end{array}$ & $\begin{array}{c}196 \\
0.292 \\
\end{array}$ & $\begin{array}{c}196 \\
0.300 \\
\end{array}$ \\
\hline
\end{tabular}

Note: robust clustered standard errors in parentheses. ***,**,* denote significance at $1 \%, 5 \%$, and $10 \%$ respectively. A constant, period, and language dummies are included but not reported for the sake of brevity. 
Table 5: Model (1), automatic and discretionary consumption volatility, OECD data sample

\begin{tabular}{|c|c|c|}
\hline Specification: & Discretionary & Automatic \\
\hline$f d \_$oecd & $\begin{array}{l}-9.49 \\
(6.34)\end{array}$ & $\begin{array}{c}-10.1 * * \\
(3.89)\end{array}$ \\
\hline landl & $\begin{array}{l}4.10 \\
(2.94)\end{array}$ & $\begin{array}{c}1.22 \\
(1.72)\end{array}$ \\
\hline island & $\begin{array}{l}-2.40 \\
(2.61)\end{array}$ & $\begin{array}{l}-2.22 \\
(1.45)\end{array}$ \\
\hline latm & $\begin{array}{c}0.027 \\
(0.053)\end{array}$ & $\begin{array}{c}0.040 \\
(0.039)\end{array}$ \\
\hline income_2 & $\begin{array}{c}1.87 \\
(2.25)\end{array}$ & $\begin{array}{c}1.16 \\
(1.24)\end{array}$ \\
\hline comecon & $\begin{array}{l}0.050 \\
(1.82)\end{array}$ & $\begin{array}{l}1.72 * \\
(0.93)\end{array}$ \\
\hline independence & $\begin{array}{c}0.0020 \\
(0.0018)\end{array}$ & $\begin{array}{c}0.0011 \\
(0.0012)\end{array}$ \\
\hline pop & $\begin{array}{l}-0.39 \\
(0.67)\end{array}$ & $\begin{array}{l}-0.25 \\
(0.44)\end{array}$ \\
\hline urban & $\begin{array}{l}-0.036 \\
(0.056)\end{array}$ & $\begin{array}{l}-0.026 \\
(0.040)\end{array}$ \\
\hline pop_dens & $\begin{array}{l}-0.0014 \\
(0.0030)\end{array}$ & $\begin{array}{l}-0.0023 \\
(0.0024)\end{array}$ \\
\hline$g d p$ & $\begin{array}{l}-0.63 \\
(1.65)\end{array}$ & $\begin{array}{c}0.65 \\
(0.91)\end{array}$ \\
\hline inflation & $\begin{array}{c}0.12 \\
(0.073)\end{array}$ & $\begin{array}{c}0.11 \\
(0.12)\end{array}$ \\
\hline open & $\begin{array}{l}-0.029 \\
(0.027)\end{array}$ & $\begin{array}{l}-0.020 \\
(0.013)\end{array}$ \\
\hline fin_open & $\begin{array}{c}1.5 \mathrm{e}-07 \\
(7.9 \mathrm{e}-07)\end{array}$ & $\begin{array}{l}-1.9 \mathrm{e}-08 \\
(4.2 \mathrm{e}-07)\end{array}$ \\
\hline fin_depth & $\begin{array}{c}0.91 \\
(1.01) \\
\end{array}$ & $\begin{array}{c}0.77 \\
(0.49) \\
\end{array}$ \\
\hline $\begin{array}{l}\text { Observations } \\
\text { R-squared }\end{array}$ & $\begin{array}{c}128 \\
0.449 \\
\end{array}$ & $\begin{array}{c}128 \\
0.509\end{array}$ \\
\hline
\end{tabular}

Note: robust clustered standard errors in parentheses. ***, **, * denote significance at 1\%, 5\%, and $10 \%$ respectively. A constant, period, and language dummies are included but not reported for the sake of brevity. 
Table 6: Model (1), three enriched versions, WB data sample and two sub-samples

\begin{tabular}{|c|c|c|c|c|c|c|c|c|c|}
\hline \multirow{2}{*}{ Specification: } & \multicolumn{3}{|c|}{ All countries } & \multicolumn{3}{|c|}{ OECD countries } & \multicolumn{3}{|c|}{ Non-OECD countries } \\
\hline & $\mathrm{D}$ & $\mathrm{D}$ & $\mathrm{D}$ & $\mathrm{D}$ & $\mathrm{D}$ & $\mathrm{D}$ & $\mathrm{D}$ & $\mathrm{D}$ & $\mathrm{D}$ \\
\hline \multirow[t]{2}{*}{$f d \_w b$} & 61.7 & 2.31 & 7.90 & -45.8 & -1.35 & -5.38 & $110.0^{*}$ & -0.78 & 20.3 \\
\hline & $(46.9)$ & $(5.40)$ & (7.97) & $(103)$ & $(4.10)$ & $(6.37)$ & $(55.9)$ & $(8.34)$ & $(14.5)$ \\
\hline \multirow[t]{2}{*}{ landl } & 1.15 & 1.28 & -1.28 & -0.56 & -2.55 & -0.24 & 2.19 & 2.48 & -0.91 \\
\hline & $(1.88)$ & $(1.73)$ & $(2.69)$ & $(1.81)$ & $(1.79)$ & $(2.10)$ & $(1.75)$ & $(1.61)$ & $(2.75)$ \\
\hline \multirow[t]{2}{*}{ island } & -0.26 & -0.40 & 0.45 & -1.06 & 1.23 & 0.023 & -1.08 & -1.42 & 0.91 \\
\hline & $(1.51)$ & $(1.67)$ & $(1.76)$ & $(2.21)$ & $(3.16)$ & $(4.06)$ & $(2.14)$ & $(2.22)$ & $(3.51)$ \\
\hline \multirow[t]{2}{*}{ latm } & 0.0083 & 0.017 & 0.080 & 0.079 & 0.062 & 0.090 & -0.045 & -0.040 & 0.074 \\
\hline & $(0.042)$ & $(0.043)$ & $(0.054)$ & $(0.065)$ & $(0.045)$ & $(0.070)$ & $(0.049)$ & $(0.054)$ & $(0.082)$ \\
\hline \multirow[t]{2}{*}{ income_2 } & 1.69 & 1.13 & 1.40 & 4.03 & $6.91 * *$ & 3.54 & 5.19 & 5.34 & $11.7 *$ \\
\hline & $(2.32)$ & $(2.20)$ & $(2.71)$ & $(2.79)$ & $(2.67)$ & $(3.06)$ & (3.34) & $(3.56)$ & $(6.07)$ \\
\hline \multirow[t]{2}{*}{ income_3 } & $5.01 *$ & $4.65^{*}$ & 5.45 & & & & $7.74 *$ & $8.43 *$ & $18.4 * *$ \\
\hline & $(2.71)$ & $(2.53)$ & $(3.61)$ & & & & (4.01) & $(4.32)$ & (8.01) \\
\hline \multirow[t]{2}{*}{ income_4 } & $8.71 * *$ & $6.34^{*}$ & 11.2 & & & & $11.7 * *$ & $10.9 *$ & $25.5 * * *$ \\
\hline & $(4.18)$ & $(3.76)$ & $(6.86)$ & & & & $(5.62)$ & $(5.80)$ & $(9.48)$ \\
\hline \multirow[t]{2}{*}{ opec } & 2.47 & 2.56 & 3.92 & & & & 1.13 & 1.36 & $7.37 *$ \\
\hline & $(2.35)$ & $(2.31)$ & $(2.44)$ & & & & $(2.83)$ & $(3.20)$ & $(4.27)$ \\
\hline \multirow[t]{2}{*}{ comecon } & $8.72 * *$ & $8.15^{* *}$ & $9.60 * *$ & 1.18 & 2.25 & 1.57 & $14.7 * *$ & $14.3^{* *}$ & $10.2 *$ \\
\hline & $(3.63)$ & $(3.39)$ & $(3.83)$ & $(3.32)$ & (1.78) & $(2.31)$ & $(5.79)$ & $(5.64)$ & $(5.40)$ \\
\hline \multirow[t]{2}{*}{ independence } & 0.00083 & 0.00039 & -0.0012 & -0.00057 & 0.00047 & 0.00065 & -0.00083 & -0.0014 & $-0.0060 * *$ \\
\hline & $(0.0013)$ & $(0.0012)$ & $(0.0015)$ & $(0.0011)$ & $(0.0011)$ & $(0.0015)$ & $(0.0011)$ & $(0.0013)$ & $(0.0028)$ \\
\hline \multirow[t]{2}{*}{ pop } & 0.41 & -0.37 & -0.95 & -0.77 & -0.69 & 0.46 & 0.14 & -0.93 & $-4.21 * * *$ \\
\hline & $(0.63)$ & $(0.33)$ & $(0.62)$ & $(1.95)$ & $(0.48)$ & $(0.80)$ & $(0.73)$ & $(0.56)$ & $(1.50)$ \\
\hline \multirow[t]{2}{*}{ urban } & 0.063 & $0.080 *$ & $0.080 *$ & 0.067 & -0.041 & 0.011 & 0.057 & 0.10 & $0.15^{*}$ \\
\hline & $(0.042)$ & $(0.045)$ & $(0.046)$ & $(0.062)$ & $(0.085)$ & $(0.088)$ & $(0.050)$ & $(0.063)$ & $(0.077)$ \\
\hline \multirow[t]{2}{*}{ pop_dens } & 0.0083 & 0.0089 & -0.0018 & -0.0099 & 0.0062 & -0.0070 & $0.017 *$ & 0.017 & $0.021 *$ \\
\hline & $(0.0080)$ & $(0.0083)$ & $(0.0058)$ & $(0.010)$ & $(0.0093)$ & $(0.0092)$ & $(0.0090)$ & $(0.010)$ & $(0.012)$ \\
\hline \multirow[t]{2}{*}{$g d p$} & -0.52 & -1.11 & -1.02 & -2.56 & 2.51 & -3.64 & 0.15 & -0.51 & -0.42 \\
\hline & (1.43) & $(1.37)$ & $(2.08)$ & $(1.95)$ & $(2.65)$ & $(2.18)$ & $(1.52)$ & (1.61) & (2.09) \\
\hline \multirow[t]{2}{*}{ inflation } & $0.0042 * * *$ & $0.0036 * * *$ & $0.0033 * *$ & -0.019 & -0.010 & 0.036 & $0.0039 * * *$ & $0.0037 * * *$ & $0.0022 *$ \\
\hline & $(0.0012)$ & $(0.0012)$ & $(0.0013)$ & $(0.028)$ & $(0.025)$ & $(0.026)$ & $(0.0011)$ & $(0.0012)$ & $(0.0012)$ \\
\hline \multirow[t]{2}{*}{ open } & 0.023 & 0.013 & 0.037 & 0.030 & 0.013 & 0.050 & 0.010 & 0.00084 & 0.0031 \\
\hline & $(0.020)$ & $(0.021)$ & $(0.025)$ & $(0.024)$ & $(0.031)$ & $(0.051)$ & $(0.021)$ & $(0.024)$ & $(0.027)$ \\
\hline \multirow[t]{2}{*}{ fin_open } & $-2.8 e-06$ & $-1.7 \mathrm{e}-06$ & $-1.2 \mathrm{e}-06$ & $5.0 \mathrm{e}-06$ & $2.6 \mathrm{e}-06$ & $2.7 e-06$ & $-4.4 \mathrm{e}-05$ & $-4.6 e-05$ & $-4.6 e-05$ \\
\hline & $(4.6 \mathrm{e}-06)$ & $(4.5 e-06)$ & $(5.0 \mathrm{e}-06)$ & $(3.8 \mathrm{e}-06)$ & $(2.5 e-06)$ & $(2.8 \mathrm{e}-06)$ & $(2.7 \mathrm{e}-05)$ & $(2.8 \mathrm{e}-05)$ & $(3.8 \mathrm{e}-05)$ \\
\hline fin_depth & 0.11 & 0.52 & 0.89 & 1.20 & -0.0048 & 0.89 & 0.41 & 0.98 & 4.59 \\
\hline & $(1.38)$ & $(1.36)$ & $(1.66)$ & $(0.98)$ & $(1.05)$ & $(1.40)$ & $(1.60)$ & (1.68) & $(3.23)$ \\
\hline$f d \_w b^{*} p o p$ & -3.60 & & & 2.70 & & & $-6.47 * *$ & & \\
\hline & $(2.82)$ & & & $(6.25)$ & & & $(3.21)$ & & \\
\hline govsize & & 0.19 & & & $1.12 * *$ & & & 0.11 & \\
\hline & & $(0.12)$ & & & $(0.46)$ & & & $(0.14)$ & \\
\hline inst_quality & & & -0.83 & & & $18.1^{*}$ & & & 3.44 \\
\hline & & & $(3.39)$ & & & $(10.2)$ & & & $(4.16)$ \\
\hline Observations & 329 & 329 & 204 & 127 & 127 & 88 & 202 & 202 & 116 \\
\hline R-squared & 0.390 & 0.398 & 0.430 & 0.555 & 0.666 & 0.582 & 0.426 & 0.410 & 0.532 \\
\hline
\end{tabular}


Note: robust clustered standard errors in parentheses. ***, **, * denote significance at $1 \%, 5 \%$, and $10 \%$ respectively. A constant, period, and language dummies are included but not reported for the sake of brevity.

Table 7: Model (1), three enriched versions, OECD data sample

\begin{tabular}{|c|c|c|c|}
\hline Specification: & $\mathrm{D}$ & $\mathrm{D}$ & D \\
\hline fd_oecd & $\begin{array}{c}-211.0 * \\
(118)\end{array}$ & $\begin{array}{c}-13.4^{* *} \\
(5.28)\end{array}$ & $\begin{array}{c}-14.2 * * \\
(6.27)\end{array}$ \\
\hline landl & $\begin{array}{c}1.69 \\
(1.79)\end{array}$ & $\begin{array}{c}2.26 \\
(2.12)\end{array}$ & $\begin{array}{c}1.32 \\
(1.90)\end{array}$ \\
\hline island & $\begin{array}{l}-6.69 * \\
(3.64)\end{array}$ & $\begin{array}{l}-3.70 \\
(2.31)\end{array}$ & $\begin{array}{l}-2.90 \\
(2.22)\end{array}$ \\
\hline latm & $\begin{array}{c}0.072 \\
(0.052)\end{array}$ & $\begin{array}{c}0.026 \\
(0.032)\end{array}$ & $\begin{array}{c}0.054 \\
(0.047)\end{array}$ \\
\hline income_2 & $\begin{array}{l}9.48 * * \\
(3.70)\end{array}$ & $\begin{array}{c}6.11 * * * \\
(1.98)\end{array}$ & $\begin{array}{c}5.62 * * \\
(2.71)\end{array}$ \\
\hline comecon & $\begin{array}{l}-3.49 \\
(2.40)\end{array}$ & $\begin{array}{l}-0.87 \\
(1.38)\end{array}$ & $\begin{array}{c}0.73 \\
(1.91)\end{array}$ \\
\hline independence & $\begin{array}{r}-0.00061 \\
(0.0014)\end{array}$ & $\begin{array}{c}0.0026^{*} \\
(0.0014)\end{array}$ & $\begin{array}{c}0.0020 \\
(0.0013)\end{array}$ \\
\hline pop & $\begin{array}{l}-5.53^{*} \\
(3.02)\end{array}$ & $\begin{array}{l}-1.15^{*} \\
(0.60)\end{array}$ & $\begin{array}{l}-0.72 \\
(0.57)\end{array}$ \\
\hline urban & $\begin{array}{l}-0.074 \\
(0.059)\end{array}$ & $\begin{array}{l}-0.040 \\
(0.037)\end{array}$ & $\begin{array}{l}-0.060 \\
(0.050)\end{array}$ \\
\hline pop_dens & $\begin{array}{c}0.0071 \\
(0.0062)\end{array}$ & $\begin{array}{c}0.0035 \\
(0.0037)\end{array}$ & $\begin{array}{c}0.0045 \\
(0.0052)\end{array}$ \\
\hline$g d p$ & $\begin{array}{c}0.22 \\
(1.88)\end{array}$ & $\begin{array}{c}1.78 \\
(1.80)\end{array}$ & $\begin{array}{l}-0.66 \\
(1.73)\end{array}$ \\
\hline inflation & $\begin{array}{l}0.027 * \\
(0.015)\end{array}$ & $\begin{array}{c}0.051 \\
(0.030)\end{array}$ & $\begin{array}{c}0.080 \\
(0.048)\end{array}$ \\
\hline open & $\begin{array}{l}-0.079 * \\
(0.041)\end{array}$ & $\begin{array}{l}-0.037 \\
(0.024)\end{array}$ & $\begin{array}{l}-0.027 \\
(0.021)\end{array}$ \\
\hline fin_open & $\begin{array}{c}1.3 \mathrm{e}-06 \\
(1.1 \mathrm{e}-06)\end{array}$ & $\begin{array}{l}-4.7 e-07 \\
(7.6 e-07)\end{array}$ & $\begin{array}{l}-9.0 e-07 \\
(8.4 e-07)\end{array}$ \\
\hline fin_depth & $\begin{array}{l}2.05^{*} \\
(1.09)\end{array}$ & $\begin{array}{c}1.15 \\
(0.85)\end{array}$ & $\begin{array}{c}1.27 \\
(0.87)\end{array}$ \\
\hline$f d \_o e c d^{*}$ pop & $\begin{array}{l}12.0 * \\
(6.91)\end{array}$ & & \\
\hline govsize & & $\begin{array}{c}0.63 * * * \\
(0.20)\end{array}$ & \\
\hline inst_quality & & & $\begin{array}{c}13.4 \\
(8.97) \\
\end{array}$ \\
\hline Observations & 130 & 130 & 120 \\
\hline R-squared & 0.592 & 0.556 & 0.574 \\
\hline
\end{tabular}

Note: robust clustered standard errors in parentheses. ***, **, * denote significance at $1 \%, 5 \%$, and $10 \%$ respectively. A constant, period, and language dummies are included but not reported for the sake of brevity. 


\section{Appendix: data sources}

- GC_vol i, $_{\text {: }}$ government consumption data are taken from Penn World Tables 7.1 (Alan Heston, Robert Summers and Bettina Aten, Penn World Table Version 7.1, Center for International Comparisons of Production, Income and Prices at the University of Pennsylvania, Nov 2012).

- $G C_{-} v l_{i, t}$ (automatic and discretionary government consumption volatility): the series are obtained by firstly estimating the following model (taken from Badinger 2009) with annual data country-by-country:

$$
\Delta \ln G C_{i, t}=\alpha_{i}+\alpha_{i} \Delta \ln G C_{i, t-1}+\beta_{i} \Delta \ln Y_{i, t}+\boldsymbol{\delta}_{i} \text { controls }_{i, t}+\varepsilon_{i, t}^{G C},
$$

where $G C$ is real government consumption, $Y$ is real GDP, $W$ is a matrix of controls (inflation, squared inflation, a time trend). Due to endogeneity concerns, $\Delta \ln Y_{i, t}$ is instrumented all other right-hand-side variables plus two lags of output growth and the logarithm of oil price (source: Dow Jones \& Company).

The five-year average of the standard deviations of the fitted values is taken as the measure of automatic stabilisers volatility. The five-year average of the standard deviations of the residuals is taken as the measure of discretionary policy.

- $\quad f d_{i, t}$ : World Bank data cover 97 countries for the period 1972-2000 and come from the Fiscal Decentralization Indicators, mainly derived from IMF's Government Finance Statistics. OECD data cover 29 countries for the period 1971-2010. Both sources offer expenditure decentralization (ed_wb and ed_oecd) and revenue decentralization data $\left(r d \_w b\right.$ and $\left.r d \_o e c d\right)$. By simply averaging the two we obtain two additional measures of fiscal decentralization $\left(f d \_w b\right.$ and $\left.f d \_o e c d\right)$.

- reg_inst set: data are taken from the website of A.K. Rose.

- demo set: these data come from the World Development Indicators (WDI) published by the World Bank.

- macro set:

○ $g d p_{i, t} \&$ b) inflation $_{i, t}$ : these data are taken from the WDI;

$\circ$ c) open $_{i, t}$ : trade openness data come from Penn World Tables 7.1.

$\circ$ d) fin_open $i, t$ : financial openness data are taken from the most up-to-date version of the External Wealth of Nations Mark II database (Lane, P.R., Milesi-Ferretti, G.M. 2007. The external wealth of nations mark II. Journal of International Economics 73, 223-250).

○ fin_depth $_{i, t}$ : financial depth data are taken from the most up-to-date version of the dataset described in Beck, T., Dermirguc-Kunt, A. (2009). Financial institutions and markets across countries and over time: data and analysis. World Bank Policy Research Working paper 4943.

- govsize: government consumption share of real GDP per capita. Source: PWT 7.1

- inst_quality: ICRG (International Risk Country Guide) indicator of quality of government, taking into account corruption, law and order, and bureaucracy quality. Source: The QOG Basic Dataset, University of Gothenburg. 


\section{List of countries:}

The 29 countries for which OECD decentralization data can be used: Austria, Belgium, Canada, Czech Republic, Denmark, Estonia, Finland, France, Germany, Hungary, Iceland, Ireland, Israel, Italy, Korea, Luxembourg, Mexico, Netherlands, New Zealand, Norway, Poland, Portugal, Slovak Republic, Slovenia, Spain, Sweden, Switzerland, the United Kingdom, the United States.

World Bank data are also available for these other countries: Albania, Argentina, Aruba, Australia, Azerbaijan, Bahrain, Bangladesh, Belarus, Benin, Bolivia, Botswana, Brazil, Bulgaria, Burkina Faso, Cameroon, Chile, China, Colombia, Democratic Republic of Congo, Republic of Congo, Costa Rica, Croatia, Cyprus, Dominican Republic, Ecuador, El Salvador, Ethiopia, Fiji, the Gambia, Guatemala, Honduras, India, Indonesia, Iran, Japan, Jordan,

Kazakhstan, Kenya, Kyrgyz Republic, Latvia, Lithuania, Madagascar, Malawi, Malaysia, Mauritius, Moldova, Mongolia, Morocco, Nicaragua, Pakistan, Panama, Papua New Guinea, Paraguay, Peru, Philippines, Romania, Russian Federation, Senegal, Somalia, South Africa, Sri Lanka, Sudan, Swaziland, Tajikistan, Thailand, Trinidad and Tobago, Tunisia, Turkey, Uganda, Uruguay, Venezuela, Zambia, Zimbabwe. 